\title{
KONSEP MEDIA PEMBELAJARAN DALAM PERSPEKTIF ALQURAN
}

\author{
Rahimi \\ STAIN Teungku Dirundeng Meulaboh \\ e-mail: rahimi.plumat85@gmail.com
}

\begin{abstract}
Media comes from Latin which means intermediary. This meaning can be said as a communication tool used to carry information from a source to a recipient. The position of learning media by them is the process of learning media is a communication process and takes place in a system, then learning media occupies an important position as one of the components of the learning system. In this case, it will be related to the accuracy of the teacher in understanding the psychological condition of students, objectives, methods and completeness of aids. All of this belongs to the form of teaching either directly or indirectly. AlQur'anul Karim is the greatest miracle of Islam and its miracles always strengthen knowledge, He was revealed by Allah to His Messenger, Muhammad SAW to bring people out of a dark atmosphere into the light and guide them to the straight path.
\end{abstract}

Keyword: Media, Learning, Alqur'an

\section{PENDAHULUAN}

Penggunaan media pembelajaran khususnya multimedia dapat meningkatkan kualitas proses belajar mengajar, yang akhirnya dapat mengukur, hasil belajar siswa serta membangkitkan keinginan dan minat baru, meningkatkan keinginan atau motivasi dan memberi rangsangan kegiatan belajar. Sedangkan pada tahap orientasi pengajaran menggunakan multimedia akan sangat membantu kegiatan belajar. Disamping membangkitkan motivasi dan minat belajar guru, maka penggunaan multimedia juga dapat membantu siswa dalam meningkatkan pemahaman siswa, penyajian data, dengan menarik dan percaya, memudahkan penafsiran data, dan memadatkan informasi dalam proses mengajar.

Pendidikan dengan mengunakan media merupakan satu hal yang sangat penting bagi setiap pendidikan bahkan bisa membawa kepada pemahaman yang lebih. Namun dalam menggunakan media sangat tergantung pada kesanggupan cara menerima dari apa yang sedang dipelajarinya. Seiring dengan perkembangan zaman sistem pendidikan juga ikut berkembang dari sistem tradisional menjadi sistem pendidikan modern, dari menggunakan metode yang sederhana terus berkembang menjadi metode yang multi lagi bervariasi. 
Media dapat digolongkan dalam suatu bentuk aspek pendorong untuk dapat melakukan suatu kegiatan yang berdasarkan sistematis cara pengelolaannya, media bukan saja meliputi sebuah perangkat lunak, akan tetapi media juga bisa dinyatakan dalam bentuk alat indra pada manusia itu sendiri. Namun yang terlebih penting tidak terlepas dari pada apa yang dinamakan dengan proses pembelajaran, artinya bilamana media pembelajaran itu berkembang dari masa ke masa, tidaklah mendapati kesulitan bagi seseorang yang memiliki kemampuan cara berfikir dan juga mampu mengimplementasikannya dalam kehidupan sehari-hari untuk dapat meningkatkan kehidupannya kearah yang lebih baik.

Orang yang menuntut ilmu tidak boleh cepat puas dengan ilmu yang sedikit dimilikinya, sementara masih banyak kemungkinan memperoleh yang lebih banyak. Jadi demikian menuntut ilmu tidak hanya puas dengan sedikit, namun terus dipelajari sepanjang hidup. Karena dengan ilmu akan menjadi petunjuk bagi orang mukmin dalam kelangsungan hidupnya didunia dan akhirat. ${ }^{1}$

Pembelajaran mengalami perkembangan dan perubahan sesuai dengan tingkat pengetahuan yang didapati dalam proses pendidikan baik mencakup pendidikan formal maupun non formal. Di pendidikan formal anak juga sudah mengenal yang dinamakan dengan media, bahkan anak pun sudah pernah dilatih dan diarahkan dalam menggunakan media baik itu media visual atau audio visual. Guru merupakan salah satu komponen dalam hal mengajar, seorang guru memiliki tanggung jawab yang besar dalam proses pembelajaran.

Oleh karena itu guru harus memberikan dorongan atau motivasi kepada kepada siswa dan selalu menuntun siswa kearah yang lebih baik. Model belajar yang dikembangkan oleh Lawrence Stohrow dan Daniel Davis "media atau alat pembelajaran juga perlu diberikan kepada siswa untuk memudahkan proses pembelajaran atau dalam hal menyampaikan materi yang akan diajarkan. Media dapat mempertinggi kualitas proses belajar mengajar yaitu dapat menimbulkan kegahiraan belajar, meningkatkan minat anak dalam belajar, membuat pembelajaran lebih merata, juga memungkinkan belajar mandiri menurut kemampuan dan minat siswa, dan juga saling dapat interaksi antar guru dan siswa atau subyek didik". ${ }^{2}$

${ }_{1}^{1}$ Abu Abdullah Muhammad, Mencari Ilmu dengan Metode Salafus Shalih, (Jakarta: Pustaka Azzam, 2001), 66. 2 Syaiful Sagala, Konsep dan Pembelajaran, (Bandung: Alfabeta), 262. 
Disamping itu, peningkatan mutu media pendidikan banyak sekali ditemukan berbagai permasalahan dan problematikanya, baik masalah yang besar maupun masalah yang kecil sering ditemukan pada media pembelajaran tersebut. Beberapa problematika pembelajaran dialami diberbagai tingkat sekolah mulai dari tingkat sekolah dasar bahkan sampai ditingkat perguan tinggi, salah satu permasalahan yang terjadi adalah rendahnya mutu sarana penunjang belajar seperti kurangnya alat atau media disekolah, hal ini dapat ditemui pada siswa yang tidak mengetahui tentang media pembelajaran artinya siswa tidak mau berusaha atau tidak berminat dengan alat media itu sendiri. Bahkan mereka lebih berminat dengan hal-hal yang tidak memiliki hasil sama sekali, mereka hanya menghabiskan waktu dalam bermain. Sehingga menimbulkan dampak turunnya mutu pendidikan. Untuk itu, dibutuhkan berbagai usaha dan upaya dalam menyelesaikan permasalahan yang terjadi dalam pendidikan.

Salah satu upaya yang harus dilakukan adalah menyetarakan sekolah tersebut dengan sekolah-sekolah yang populer dalam arti, harus dapat meningkatkan mutu pembelajaran dengan menggunakan media sebagai sarana pembelajaran. Kemudain pemberiakan motivasi terhadap guru maupun siswa, untuk giat dalam belajar dan mengajar sehingga diharapkan tujuan pendidikan yang telah ditetapkan dapat tercapai. ${ }^{3}$ Berdaskan pokok-pokok pemikiran diatas penulis ingin menganalisa dan mengkaji lebih dalam tentang permasalahan media dalam meningkatkan mutu pembelajaran. Ada pun alasan penulis hanya untuk mengetahui sejauh mana kemampuan peserta didik yang memahami media dalam hasil belajarnya.

\section{PEMBAHASAN}

\section{A. Konsep Menggunakan Media Dalam Alqur'an}

Penggunaan media sebenarnya dianjurkan, pada hakikatnya Allah telah menciptakan manusia dari penciptaan yang sangatlah sempurna. Dimana pada mulanya Allah memberikan kepada manusia itu berbagai macam nikmat diantaranya, Allah memberikan nikmat mata, yakni sebagai alat untuk melihat seluruh penciptaanNya. Mata adalah suatu anugerah dari yang Maha kuasa, tanpa nikmat mata kita tidak bisa melihat bahkan juga tidak dapat membedakan antara siang dengan malam, dan malam sudah

${ }^{3}$ Mohd. Uzer Usman, Menjadi Guru Profesional, (Bandung: Remaja Rosda Karya, tt), 83. 
tentu malam begitu juga hal-hal yang lain. Bila kita menyadari bahwa mata ini sangatlah penting, kerena dengan mata kita dapat merasakan kenikmatan dunia dan juga bisa melihat keindahan alam semesta yang begitu luas dan penuh variasi. Maka oleh sebab itu pergunakanlah mata atau penglihatan kepada haknya dalam arti menggunakannya ke jalan yang Allah ridhai bukan jalan yang dimurkai Allah SWT.

Mata juga dapat dijadikan sebagai alat pembelajaran disaat kita membaca, menulis, menggambar dan lain sebagainya. Mata sangatlah berperan aktif dalam kehidupan baik dalam belajar atau bukan. Penerapan media penglihatan disaat proses pembelajaran, bisa dicontohkan pada saat menggajarkan fikih. Media pembelajaran fikih, khususnya media pembelajaran visual (penglihatan) alat indra yang digukan adalah mata. Yang merupakan rangkaian kegiatan atau cerita disajikan secara beurutan. Siswa berlatih mengungkapkan adegan dan kegiatan-kegiatan tersebut yang apabila dirangkaikan akan menjadi suatu cerita.

Dalam menerapkan media pembelajaran fikih tersebut seorang guru perlu memperhatikan hal-hal sebagai berikut:, merumuskan tujuan pengajaran dengan memanfaatkan media. Persiapan guru dengan cara memilih dan menetapkan media mana yang akan dimanfaatkan guna mencapai tujuan. Begitu juga dengan mengunakan alat media yang lain seperti telinga, hidung, mulut, tangan, kaki, bahkan yang sangat terpenting adalah hati. Hati juga sering disebut dalam kata lain dengan sebutan "qhalbu" yaitu hati. Hati sangatlah mempengaruhi didalam segala hal baik itu menyangkut hubungan dengan Allah maupun sesama manusia itu sendiri. Karena hati ini bersifat kreatifitas, dalam arti kata hati bisa saja cendrung kepada kebaikan mungkin juga sebaliknya yaitu kepada kejahatan. Sebagaimana firman Allah dalam Alquran surat AlBaqarah ayat 10. Adapaun manfaat dari media pembelajaran dalam proses belajar mengajar adalah, antara lain :

1. Pengajaran akan lebih menarik perhatian mahasiswa sehingga dapat menumbuhkan motivasi belajar.

2. Bahan pengajaran akan lebih jelas maknanya sehingga lebih dipahami peserta didik.

3. Metode pembelajaran akan lebih bervariasi, tidak semata-mata komunikasi verbal melalui peraturan kata-kata dosen, sehingga mahasiswa tidak bosan dan dosen tidak kehabisan tenaga. 
4. Mahasiswa akan lebih banyak melakukan kegiatan belajar, sebab tidak hanya mendengarkan uraian dosen, tetapi aktifitas lain seperti mengamati, melakukan, mendemontrasikan dan lain-lain.

\section{B. Anjuran Alqur'an Menggunakan Media Sebagai Alat Pembelajaran}

Dunia pendidikan di Indonesia sampai saat ini masih memprihatinkan. Realitas dunia pendidikan Indonesia saat ini tampaknya menunjukkan semakin terpisahnya antara apa yang dipelajari di bangku sekolah dengan pengalaman konkret dalam masyarakat. Belum lagi, biaya pendidikan bagi rakyat kecil seolah masih menjadi 'barang mahal'. Dengan berbagai problem yang mengitari dunia pendidikan Indonesia, setidaknya ada dua hal yang menjadi konteks reformasi pendidikan Indonesia. Pertama, tentang sistem pendidikan di Indonesia dan perubahanperubahan besar yang terjadi sejak diterapkannya sistem sosial-politik yang demokratis, yang berdampak signifikan pada dunia pendidikan. Kedua, reformasi manajemen dan kurikulum yang telah mengikuti perubahan politik, nilai-nilai, cara berpikir yang diwujudkannya. ${ }^{4}$

Jika menengok model-model maupun metode dan paradigma pandidikan yang ditemukan para sarjana barat, sangat komplek sekali. Namun dalam hal ini, akan dikaji dari penafsiran Alqur'an, terutama surat an-Nabl ayat. 78 Hal ini beralasan, Alqur'an dan Hadis merupakan rujukan utama kaum muslimin dalam berbagai aktifitas termasuk, pendidikan dalam ayat di atas, Allah menerangkan kekuasaan-Nya yang sempurna dan pengetahuan-Nya terhadap segala kegaiban langit dan bumi. Semua itu hanya dimiliki Allah. Maka tiada seorang pun yang dapat melihat kegaiban kecuali jika Allah memperlihatkan sesuatu yang dikehendaki-Nya kepada seseorang. Sedangkan, Sayyid Quthub menjadikan ayat ini sebagai pemaparan contoh sederhana dalam kehidupan manusia yang tidak dapat terjangkau oleh manusia, yakni kelahiran, padahal itu terjadi setiap saat. Mungkin manusia dapat melihat tahap pertumbuhan janin, tetapi dia tidak mengetahui bagaimana hal tersebut terjadi, karena rahasianya merupakan rahasia kehidupan. ${ }^{5}$

Sesudah mencapai kesempurnaan, Allah mengeluarkan manusia itu dari rahim ibu, pada waktu itu dia tidak mengetahui sesuatu. Akan tetapi, sewaktu masih dalam rahim, Allah swt. menganugerahkan kesediaan-kesediaan (bakat) dan kemampuan

\footnotetext{
${ }^{4}$ Raihani, Kepemimpinan Sekolah Transformatif, (Yogyakarta: LKiS, 2010), 53.
}

5 M. Quraish Shihab, Tafsir al-Misbah, (Jakarta: Lentera Hati, 2010), 307. 
pada diri manusia, seperti bakat berpikir, berbahagia, mengindra dan lain sebagainya. Setelah manusia itu lahir, dengan hidayah Allah segala bakat-bakat itu berkembang. Akalnya dapat memikirkan tentang kebaikan, kejahatan, kebenaran dan kesalahan, hak dan batal. Dan dengan bakat pendengaran dan penglihatan yang telah berkembang itu manusia mengenali dunia sekitanya dan mempertahankan hidupnya serta mengadakan hubungan sesama manusia. Dan dengan perantaraan akal dan indra itu pengalaman dari pengetahuan manusia dari hari ke hari semakin bertambah dan berkembang. Ayat di atas menggunakan kata as-sama' dengan bentuk tunggal dan menempatkannya sebelum kata al-abshar yang berbentuk jamak serta al-afidah yang juga berbentuk jamak. Makna ini dapat diterima jika yang dimaksud dengannya adalah gabungan daya pikir dan daya qalbu, yang menjadikan seseorang terikat sehingga tidak terjerumus dalam kesalahan dan kedurhakaan. Dengan demikian tercakup dalam pengertiannya potensi meraih ilham dan percikan cahaya ilahi. Didahulukannya kata pendengaran atas penglihatan, merupakan perurutan yang sungguh tepat, karena memang ilmu kedokteran modern membuktikan bahwa indera pendengaran berfungsi mendahului indera penglihatan. Daya dan indra ini diperoleh manusia secara berangsur-angsur. Setiap kali tumbuh, bertambahlah daya pendengaran, penglihatan, dan akalnya hingga dewasa. Penganugerahan daya itu dimaksudkan agar dia dapat beribadah kepada Rabbnya dan dijadikan sarana ketaatan kepada Allah swt. Aspek lain, ayat di atas menunjuk kepada alat-alat pokok yang digunakan untuk meraih (ilmu) pengetahuan. Alat pokok pada objek yang bersifat material adalah mata dan telinga, sedang pada objek yang bersifat immaterial adalah akal dan hati.

Dipilihnya bentuk jamak untuk penglihatan dan hati, karena yang didengar selalu saja sama, baik oleh seorang maupun banyak orang dan dari arah mana pun datanganya suara. Ini bebeda dengan apa yang dilihat. Posisi tempat berpijak dan arah pandang melahirkan perbedaan. Demikian juga hasil kerja akal dan hati, hati manusia terkadang senang, satu waktu susah, benci dan sekali rindu, tingkat-tingkatnya berbeda-beda walau objek yang dibenci dan dirindui sama. Hasil penalaran akal pun demikian, Ia dapat berbeda, boleh jadi ada yang sangat jitu dan tepat, dan boleh jadi juga merupakan kesalahan fatal. Istilahnya, kepala sama berambut, tetapi pikiran berbeda-beda. 
Dalam pandangan Alquran ada wujud yang tidak tampak, sekalipun tajamnya penglihatan atau pikiran. Banyak hal yang tidak dapat terjangkau oleh indera, bahkan oleh akal manusia. Yang dapat menangkapnya hanyalah hati, melalui wahyu, ilham, dan keimanan. Dengan begitu Alqur'an, di samping menuntun dan mengarahkan pendengaran dan penglihatan, juga memerintahkan agar mengasah akal, yakni daya pikir dan mengasuh pula daya kalbu. Akal dalam arti daya pikir hanya mampu berfungsi dalam batas-batas tertentu. Ia tidak mampu menuntun manusia keluar jangkauan alam fisika ini. Bidang operasinya adalah bidang alam nyata, dan dalam bidang ini pun terkadang manusia teperdaya oleh kesimpulan-kesimpulan akal, sehingga hasil penalaran akal tidak merupakan jaminan bagi seluruh kebenaran.

\section{Bentuk Media Pembelajaran Dalam Alquran Surat An-Nahl Ayat 78}

Seperti halnya media pembelajan sebagaimana yang tersebut dalam Alquran pada surat an-Nahl ayat 78 yang artinya "Dan Allah mengeluarkan kamu dari perut ibumu dalam keadaan tidak mengetahui sesuatupun, dan Dia memberi kamu pendengaran, penglihatan dan hati, agar kamu bersyukur”.

Begitupun dengan Hadits kewajiban menuntut ilmu, hadits tersebut harus bersandarkan kepada Alquran. Sebagaiman dalam surat Al-Alaq yang artinya "Bacalah dengan (menyebut) nama Tuhanmu yang Menciptakan (1), Dia telah menciptakan manusia dari segumpal darah (2). Bacalah, dan Tuhanmulah yang Maha Pemurah (3), Yang mengajar (manusia) dengan perantaran kalam (4), Dia mengajar kepada manusia apa yang tidak diketahuinya (5)”.

Dalam pandangan Quraish Shihab kata Iqra' terambil dari akar kata yang berarti menghimpun. Dari menghimpun lahir aneka makna seperti menyampaikan, menelaah, mendalami, meneliti, mengetahui ciri sesuatu, dan membaca teks tertulis maupun tidak. Wahyu pertama itu tidak menjelaskan apa yang harus dibaca, karena Alquran menghendaki umatnya membaca apa saja selama bacaan tersebut bismi Rabbik, dalam arti bermanfaat untuk kemanusiaan. Iqra' berarti bacalah, telitilah, dalamilah, ketahuilah ciri-ciri sesuatu; bacalah alam, tanda-tanda zaman, sejarah, maupun diri sendiri, yang tertulis maupun yang tidak. Hasilnya, objek perintah iqra' mencakup segala sesuatu yang dapat dijangkaunya.

Kemudian, dalam Alquran surat al-Baqarah ayat 31 yang artinya "Allah mengajarkan kepada Adam nama-nama (benda-benda) seluruhnya, kemudian Dia 
perlihatkan kepada malaikat, seraya berfirman, Sebutkan kepada-Ku nama sebuah benda ini, jika kamu yang benar”.

Dimaksud nama-nama pada ayat tersebut adalah sifat, ciri, dan hukum sesuatu. Ini berarti manusia berpotensi mengetahui rahasia alam raya. Adanya potensi itu, dan tersedianya lahan yang diciptakan Allah, serta ketidakmampuan alam raya membangkang terhadap perintah dan hukum-hukum Tuhan, menjadikan ilmuwan dapat memperoleh kepastian mengenai hukum-hukum alam. Karenanya, semua itu mengantarkan manusia berpotensi untuk memanfaatkan alam yang telah ditundukkan Tuhan.

Ketika Nabi Muhammad masih remaja beliau banyak berjumpa dengan pedagang dari dalam dan luar negri Arab salah satunya dari China karna dahulu jarak dari Mekkah ke China sangat jauh Maka lahirlah hadis yang artinya"Uttlubul Ilmi walaubi Sbin". Melihat dimana Negeri China adalah salah satu Negara Asia pertama yang bisa membuat kertas dan tinta untuk menulis. Melihat realita tersebut, maka munculah hadits "Tholabul Ilmi Faidhatun Ala Kulli Muslimin Wal Muslimati ..." Yang menjadikan bahwa mununtut ilmu itu penting bagi setiap muslim. Meskipun kemudian lahir teori Barat bahwa pendidikan itu kebutuhan bukannya kewajiban. Islam telah lama mewajibkan hal tersebut karena hal itu memang sangat dibutuhkan oleh kaum muslimin. Sebagaimana ada pefatah kaum Sufi "Allah tidak pernah memberikan apa yang kita inginkan tetapi apa yang kita butuhkan". Jika meminjam istilah agama, maka anugerah Allah yang pertama dapat digolomgkan dalam istilah "Nikmat Maubibi ", artinya nikmat yang diberikn oeh Allah kepada manusia secara gratis dan tinggal pakai. Sementara anugerah Allah yang kedua dapat digolongkan dalam istilah "Nikmat Kasabi ", yakni nikmat yang tidak diberikan secara gratis, sehingga manusia dituntut untuk memiliki daya saing yang tinggi agar dapat memperolehnya dengan sebanyak-banyaknya. Sejarah telah membuktikan bahwa bumi ini dalam bidang apapun pasti dikuasai oleh suatu bangsa yang SDMnya jauh lebih tinggi dan penguasaan IPTEK-nya jauh lebih maju, sedangkan bangsa yang SDM-nya rendah dan tertinggal pasti menjadi jajahannya, baik secara langsung maupun tidak langsung. Adapun anugerah Allah yang ketiga dalam satu sisi merupakan Nikmat Kasabi, karena manusia diberi hak memilih diantara mau mengikuti petunjuk hidup yang tertuang dalam ajaran Alqur'an dan sunnah Rasul atau menolaknya. Tetapi dalam sisi lain tergolong Nikmat Mauhibi, karena 
pemberian petunjuk hidup itu merupakan hak prerogatif Allah sehingga Rasulullah sendiri hanya diberi hak untuk menyampaikannya saja, bukan memberikannya.

\section{Aplikasi Media Pembelajaran Menurut Alqur'an Dalam Kehidupan}

Alat-alat yang dianugerahkan Allah, yang telah disebutkan di atas, masih belum digunakan oleh umat Islam, bahkan para penuntut ilmu secara sempurna. Kalimat la ta'lamuna syai an dalam ayat di atas sebagai bukti bahwa manusia lahir tanpa sedikitpun pengetahuan. Manusia bagaikan kertas putih yang belum dibubuhi satu huruf pun. Pendapat ini benar jika yang dimaksud dengan pengetahuan adalah pengetahuan kasbiy, yakni yang diperoleh melalui upaya manusiawi. Tetapi ia meleset jika menafikan segala macam pengetahuan, karena manusia lahir membawa fitrah kesucian yang melekat pada dirinya sejak lahir, yakni fitrah yang menjadikannya mengetahui bahwa Allah Maha Esa. Dengan demikian, aspek pendidikan sangat dibutuhkan dalam kehidupan manusia secara batiniah maupun lahiriah. Dengan pendidikan manusia akan menjadi makhluk yang melakukan perubahan di bumi. Untuk melangsungkan tugasnya sebagai khalifah di bumi manusia harus mengenyam pendidikan. Pendidikan sebagai penopang keberlangsungan manusia dalam beribadah.

Kalau ditelusuri dalam Alquran, banyak sekali ayat yang berkaitan dengan pendidikan. Terdapat ayat menekankan pentingnya berpikir, meneliti, dan memahami realitas secara keseluruhan, dan sebagainya. Bahkan, ayat pertama diturunkan adalah ayat yang secara tekstual memerintahkan untuk membaca. Membaca tentu terkait dengan belajar, dan belajar berkaitan dengan pendidikan. Membaca justru menjadi inti dari pendidikan. Lewat membaca akan diperoleh informasi dan kekayaan khazanah yang tidak terbatas. Jika dianalogikan secara mendalam, ilmu tidak akan diperoleh secara maksimal kecuali melalui jalur pendidikan. Pendidikan memiliki makna yang sangat penting dalam kehidupan. Makna penting pendidikan ini telah menjadi kesepakatan luas dari setiap elemen masyarakat. Lewat pendidikan, bisa diukur maju mundurnya suatu negara. Sebuah negara akan tumbuh pesat dan maju dalam segenap kehidupan jika ditopang oleh pendidikan yang berkualitas. ${ }^{6}$ Dengan demikian, signifikansi pendidikan juga

${ }^{6}$ As'aril Muhajir, Imu Pendidikan Perspektif Kontekstual, (Yogyakarta: Ar-Ruzz Media, 2011), 4. 
menjadi perhatian dalam ajaran Islam. Karena Islam menempatkan pendidikan pada posisi yang sangat vital.

\section{E. Fungsi Media Pembelajaran Menurut Alquran Dalam Kehidupan}

Media merupakan salah satu komponen dalam proses belajar mengajar yang sangat diperlukan, mengingat bahwa kedudukan media ini bukan hanya sekedar alat bantu mengajar, tapi juga merupakan bagian integral dalam pembelajaran. Selain dapat menggantikan sebagai tugas guru sebagai penyaji materi (penyalur pesan) media juga memiliki potensi unik yang dapat membantu siswa dalam meningkatkan motivasi proses belajar mengajar pendidikan agama Islam. Oleh karena itu media pembelajaran dapat dikatakan sebagai sumber belajar yang dapat membantu mencapai tujuan dari pembelajaran pendidikan agama Islam dalam meningkatkan motivasi dalam proses belajar mengajar pendidikan agama Islam. Berdasarkan latar belakang diatas maka peneliti mengangkat beberapa masalah yaitu,

1. Media pembelajaran apa saja yang digunakan oleh guru dalam proses belajar mengajar pendidikan agama Islam,

2. Bagaimana peranan media pembelajaran terhadap motivasi belajar pendidikan agama Islam,

3. Faktor-faktor apa yang menjadi pendukung dan penghambat penggunaan media pembelajaran terhadap motivasi belajar pendidikan agama Islam. Adapun penelitian inibertujuan untuk:

4. Untuk mengidentifikasi media yang digunakan oleh guru dalam proses belajar mengajar pendidikan agama Islam.

5. Untuk mendiskripsikan peranan media pembelajaran terhadap motivasi belajar pendidikan agama Islam.

6. Untuk mengidentifikasi faktor-faktor apa yang menjadi pendukung danpenghambat penggunaan media pembelajaran terhadap motivasi belajar pendidikan agama Islam.

Dalam tafsir Al Maraghi mengandung penjelasan bahwa setelah Allah melahirkan kamu dari perut ibumu, maka Dia menjadikan kamu dapat mengetahui segala sesuatu yang sebelumnya tidak kamu ketahui. Dia telah memberikan kepadamu beberapa macam anugerah berikut ini :

1. Akal; berfungsi sebagai alat untuk memahami sesuatu,terutama dengan akal itu kamu dapat membedakan antara yang baik dan yang jelek, antar yang lurus dan yang sest, antara yang benar dan yang salah. 
2. Pendengaran; sebagai alat untuk mendengarkan suara, terutama dengan pendengaran itu kamu dapat memahami percakapan diantara kamu.

3. Penglihatan; sebagai alat untuk melihat segala sesuatu, terutama dengan penglihatan itu kamu dapat saling mengenal diantara kamu.

4. Perangkat hidup yang lain; sehingga kamu dapat mengetahui jalan untuk mencari rizki dan materi lainnya yang kamu butuhkan, bahkan kamu dapat pula memilih mana yang terbaik bagi kamu dan meninggalkan mana yang jelek atau yang tidak baik.

Semua yang dianugerahkan oleh Allah kepadamu tiada maksud lain kecuali supaya kamu bersyukur, artinya kamu gunakan semua anugerah Allah tersebut diatas semata-mata untuk mencapai tujuan hidup yang sebenarnya yaitu mengekploitasi sebanyak-banyak karunia Allah yang tersebar di seluruh belahan bumi-Nya demi kemaslaahatan hidup umat manusia dan meraih keridaan-Nya, karena dengan keridhaan-Nya itulah hidupmu menjadi semakin bermartabat. Begitulah selayaknya yang harus dilakukan oleh setiap manusia sesuai tugas hidupnya sebagai hamba Allah dan khalifahnya di muka bumi.

Semua anugerah Allah yang disebutkan dalam Surat An Nahl : 78 pada hakekatnya hanya merupakan sebagian saja, karena secara global anugerah Allah itu dapat dipaparkan dalam 5 macam :

1. Hidayatul Gharizah, yakni anugerah Insting, seperti halnya bayi menangis karena pantasnya.

2. Hidayatul Hawasy, artinya anugerah Panca Indera

3. Hidayatul Aqli, yakni anugerah Akal Pikiran.

4. Hidayatul Din, artinya anugerah Petunjuk Agama.

5. Hidayatul Irsyad wa Taufiqi, yakni anugerah Pengarahan dan Bimbingan.

Anugerah petunjuk agama belum bisa menjamin manusia mampu melaksanakan tugas hidupmya, karena petunjuk agama itu hanya disampaikan saja sehingga tergantung manusianya, mengikuti petunjuk agama atau tidak. Karena itu, bagi manusia masih diperlukan lagi anugerah Pengarahan dan Bimbingan langsung dari Allah SWT. Ayat diatas menyatakan bahwa manusia saat dilahirkan dalam keadaan tidak tahu apa-apa, tetapi Allah memberikan telinga untuk mendengar, mata untuk melihat, dan hati untuk berpikir serta merasakan. Untuk menggunakan telinga, mata dan hati secara baik daan bermanfaat dilakukan proses pendidikan belajar antara 
lain membaca dengan perantaraan kalam agar manusia menjadi berkualitas dan sempurna kehidupannya. Oleh karena itu untuk menjadi manusia yang sempurna dan berkualitas diperlukan proses pendidikan dan pembudayaan agar manusia yang terlahir dari ibunya memiliki pengetahuan, ketrampilan, dan norma norma sesuai dengan potensi yang dimilikinya.

Sedangkan, Sayyid Quthub menjadikan ayat ini sebagai pemaparan contoh sederhana dalam kehidupan manusia yang tidak dapat terjangkau oleh manusia, yakni kelahiran, padahal itu terjadi setiap saat. Mungkin manusia dapat melihat tahap pertumbuhan janin, tetapi dia tidak mengetahui bagaimana hal tersebut terjadi, karena rahasianya merupakan rahasia kehidupan. ${ }^{7}$ Sesudah mencapai kesempurnaan, Allah mengeluarkan manusia itu dari rahim ibu, pada waktu itu dia tidak mengetahui sesuatu. Akan tetapi, sewaktu masih dalam rahim, Allah swt. menganugerahkan kesediaan-kesediaan (bakat) dan kemampuan pada diri manusia, seperti bakat berpikir, berbahagia, mengindra dan lain sebagainya. Setelah manusia itu lahir, dengan hidayah Allah segala bakat-bakat itu berkembang. Akalnya dapat memikirkan tentang kebaikan, kejahatan, kebenaran dan kesalahan, hak dan batal. Dan dengan bakat pendengaran dan penglihatan yang telah berkembang itu manusia mengenali dunia sekitanya dan mempertahankan hidupnya serta mengadakan hubungan sesama manusia. Dan dengan perantaraan akal dan indra itu pengalaman dari pengetahuan manusia dari hari ke hari semakin bertambah dan berkembang.

Ayat di atas menggunakan kata as-sama' dengan bentuk tunggal dan menempatkannya sebelum kata al-abshar yang berbentuk jamak serta al-afidah yang juga berbentuk jamak. Kata yang terakhir dipahami oleh banyak ulama dalam arti akal. Makna ini dapat diterima jika yang dimaksud dengannya adalah gabungan daya pikir dan daya kalbu, yang menjadikan seseorang terikat sehingga tidak terjerumus dalam kesalahan dan kedurhakaan. Dengan demikian tercakup dalam pengertiannya potensi meraih ilham dan percikan cahaya ilahi.

Didahulukannya kata pendengaran atas penglihatan, merupakan perurutan yang sungguh tepat, karena memang ilmu kedokteran modern membuktikan bahwa indera pendengaran berfungsi mendahului indera penglihatan. Daya dan indra ini diperoleh manusia secara berangsur-angsur. Setiap kali tumbuh, bertambahlah daya

${ }^{7}$ M. Quraish Shihab, Tafsir al-Misbah, (Jakarta: Lentera Hati, 2010), 307. 
pendengaran, penglihatan, dan akalnya hingga dewasa. Penganugerahan daya itu dimaksudkan agar dia dapat beribadah kepada Rabbnya dan dijadikan sarana ketaatan kepada Allah swt. Aspek lain, ayat di atas menunjuk kepada alat-alat pokok yang digunakan untuk meraih (ilmu) pengetahuan. Alat pokok pada objek yang bersifat material adalah mata dan telinga, sedang pada objek yang bersifat immaterial adalah akal dan hati. Dipilihnya bentuk jamak untuk penglihatan dan hati, karena yang didengar selalu saja sama, baik oleh seorang maupun banyak orang dan dari arah mana pun datanganya suara. Ini bebeda dengan apa yang dilihat. Posisi tempat berpijak dan arah pandang melahirkan perbedaan. Demikian juga hasil kerja akal dan hati, hati manusia terkadang senang, satu waktu susah, benci dan sekali rindu, tingkat-tingkatnya berbeda-beda walau objek yang dibenci dan dirindui sama. Hasil penalaran akal pun demikian. Ia dapat berbeda, boleh jadi ada yang sangat jitu dan tepat, dan boleh jadi juga merupakan kesalahan fatal. Istilahnya, kepala sama berambut, tetapi pikiran berbeda-beda.

Pandangan Alqur'an ada wujud yang tidak tampak, sekalipun tajamnya penglihatan atau pikiran. Banyak hal yang tidak dapat terjangkau oleh indera, bahkan oleh akal manusia. Yang dapat menangkapnya hanyalah hati, melalui wahyu, ilham, dan keimanan. Dengan begitu Alqur'an, di samping menuntun dan mengarahkan pendengaran dan penglihatan, juga memerintahkan agar mengasah akal, yakni daya pikir dan mengasuh pula daya qalbu. Akal dalam arti daya pikir hanya mampu berfungsi dalam batas-batas tertentu. Ia tidak mampu menuntun manusia keluar jangkauan alam fisika ini. Bidang operasinya adalah bidang alam nyata, dan dalam bidang ini pun terkadang manusia teperdaya oleh kesimpulankesimpulan akal, sehingga hasil penalaran akal tidak merupakan jaminan bagi seluruh kebenaran. Alat-alat yang dianugerahkan Allah, yang telah disebutkan di atas, masih belum digunakan oleh umat Islam, bahkan para penuntut ilmu secara sempurna.

Kalimat la ta'lamuna syai an dalam ayat di atas sebagai bukti bahwa manusia lahir tanpa sedikitpun pengetahuan. Manusia bagaikan kertas putih yang belum dibubuhi satu huruf pun. Pendapat ini benar jika yang dimaksud dengan pengetahuan adalah pengetahuan kasbiy, yakni yang diperoleh melalui upaya manusiawi. Tetapi ia meleset jika menafikan segala macam pengetahuan, karena manusia lahir membawa fitrah kesucian yang melekat pada dirinya sejak lahir, yakni 
fitrah yang menjadikannya mengetahui bahwa Allah Maha Esa. Dengan demikian, aspek pendidikan sangat dibutuhkan dalam kehidupan manusia secara batiniah maupun lahiriah. Dengan pendidikan manusia akan menjadi makhluk yang melakukan perubahan di bumi. Untuk melangsungkan tugasnya sebagai khalifah di bumi manusia harus mengenyam pendidikan. Pendidikan sebagai penopang keberlangsungan manusia dalam beribadah.

Kalau ditelusuri dalam Alqur'an, banyak sekali ayat yang berkaitan dengan pendidikan. Terdapat ayat menekankan pentingnya berpikir, meneliti, dan memahami realitas secara keseluruhan, dan sebagainya. Bahkan, ayat pertama diturunkan adalah ayat yang secara tekstual memerintahkan untuk membaca. Membaca tentu terkait dengan belajar, dan belajar berkaitan dengan pendidikan. Membaca justru menjadi inti dari pendidikan. Lewat membaca akan diperoleh informasi dan kekayaan khazanah yang tidak terbatas. Jika dianalogikan secara mendalam, ilmu tidak akan diperoleh secara maksimal kecuali melalui jalur pendidikan. Pendidikan memiliki makna yang sangat penting dalam kehidupan. Makna penting pendidikan ini telah menjadi kesepakatan luas dari setiap elemen masyarakat. Lewat pendidikan, bisa diukur maju mundurnya suatu negara. Sebuah negara akan tumbuh pesat dan maju dalam segenap kehidupan jika ditopang oleh pendidikan yang berkualitas. ${ }^{8}$

\section{KESIMPULAN}

Media dapat digolongkan dalam suatu bentuk aspek pendorong untuk dapat melakukan suatu kegiatan yang berdasarkan sistematis cara pengelolaannya, media bukan saja meliputi sebuah perangkat lunak, akan tetapi media juga bisa dinyatakan dalam bentuk alat indra pada manusia itu sendiri. Kita perlu menyadari bahwa mata ini sangatlah penting, kerena dengan mata kita dapat merasakan kenikmatan dunia dan juga bisa melihat keindahan alam semesta yang begitu luas dan penuh variasi. Maka oleh sebab itu pergunakanlah mata atau penglihatan kepada haknya dalam arti menggunakannya ke jalan yang Allah ridhai bukan jalan yang dimurkai Allah SWT. Setelah manusia itu lahir, dengan hidayah Allah segala bakat-bakat itu berkembang.

\footnotetext{
8 As'aril Muhajir, Imu Pendidikan Perspektif Kontekstual, (Yogyakarta: Ar-Ruzz Media, 2011). 4.
} 
Akalnya dapat memikirkan tentang kebaikan, kejahatan, kebenaran dan kesalahan, hak dan batal.

\section{DAFTAR PUSTAKA}

Abdullah Muhammad, Abu, Mencari Ilmu dengan Metode Salafus Shalih, Jakarta: Pustaka Azzam, 2001.

Sagala, Syaiful, Konsep dan Pembelajaran, Bandung: Alfabeta.

Uzer Usman, Mohd., Menjadi Guru Profesional, Bandung: Remaja Rosda Karya, tt.

Raihani, Kepemimpinan Sekolah Transformatif, Yogyakarta: LKiS, 2010.

Quraish Shihab, M., Tafsir al-Misbah, Jakarta: Lentera Hati, 2010.

Muhajir, As'aril, Ilmu Pendidikan Perspektif Kontekstual, Yogyakarta: Ar-Ruzz Media, 2011. 